\title{
可視・近赤外分光法によるダイコンバーティシリウム黒点病症状の非破壊計測
}

\author{
小宮山誠一 ${ }^{1 *} \cdot$ 相馬ちひろ ${ }^{1} \cdot$ 鳥越昌隆 $^{2} \cdot$ 五十嵐正和 $^{3}$ \\ ${ }^{1}$ 北海道立中央農業試験場 $\quad 069-1395$ 北海道夕張郡長沼町 \\ 2 北海道立十勝農業試験場 $\quad 082-0081$ 北海道河西郡芽室町 \\ ${ }^{3}$ 三菱農機株式会社札幌施設部 066-0077 北海道千歳市
}

\section{Nondestractive Determination of the Symptom of Verticillium Black Spot in Japanese Radish Using Visible and Near-infrared Spectoroscopy}

\author{
Seiichi Komiyama ${ }^{1}$, Chihiro Souma ${ }^{1}$, Masataka Torikoshi ${ }^{2}$ and Masakazu Igarashi ${ }^{3}$ \\ ${ }^{1}$ Hokkaido Central Agricultural Experiment Station, Naganuma, Hokkaido 069-1395 \\ ${ }^{2}$ Hokkaido Tokachi Agricultural Experiment Station, Memuro, Hokkaido 082-0081 \\ ${ }^{3}$ Mitsubishi Agricultural Machinery Co., Ltd., Chitose, Hokkaido 066-0077
}

\begin{abstract}
The symptom of Verticillium black spot in Japanese radish (Raphanus sativus L.) is black discoloration at the vascular bundle of the root: However, it is difficult to detect the symptom by visual inspection. Thus diseased roots are often mixed with normal roots after inspection in packinghouses. So we attempted to develop a nondestractive determination method using visible (VIS) and near-infrared (NIR) spectoroscopy under practical conditions. The spectra of radish roots were continuously measured by transmittance mode: the scanning range was 450-1,000 nm. Measured roots were then cut and the degree of symptom was converted to an index of 0 (no symptom) to 3 (severely affected) by visual inspection of the cut root. Partial least squares regression was carried out relative to the indices to the second derivative spectra. In a validation set, the standard error of prediction for the index was $0.299(\mathrm{R}=0.958, \mathrm{n}=70)$. For each root without the symptom, the predicted indices were less than one, and for $91 \%$ of the roots with the symptom, the predicted indices were more than one. Using this method, the roots with an index of 0 could be completely separated from those with an index 2 or higher. It is suggested that VIS/NIR spectroscopy is an effective tool for accurate and rapid elimination of radish roots with the internal symptom of Verticillium black spot.
\end{abstract}

Key Words : PLSR, rapid evaluation, second derivative spectra, transmittance

キーワード : 迅速評価, 2 次微分スペクトル, PLS 回帰分析，透過光

\section{緒言 \\ ダイコンの難防除病害であるバーティシリウム黒点病} は, Verticillium dahliae（北沢・鈴井，1980）およびV.alboatrum（角野ら, 1997）の感染により発生し, 根部には維管 束の黒変症状が発現する (第 1 図). 本病は北海道内で広く 発生し，生産現場で適用可能な防除技術が開発されてきた が（角野ら，2001a, b; 小松ら，2001a,b), 根絶には至らず, 今なお各地で発生がみられる. 根部に発生する黒変症状は 外観で判別することが困難なため, 選果受け入れ時に各 ロット（搬入用コンテナ約 500 本入り）から 5 〜 15 本を抜 き取り，根部を切断して内部検査を実施している．しかし ながら, 全量検査ではないため本症状のあるダイコンを含 むロットが選果場での検査を通過して流通され，クレーム

2009 年 6 月 25 日 受付. 2009 年 9 月 10 日 受理.

* Corresponding author. E-mail: komiyasi@agri.pref.hokkaido.jp
が発生する事例がある。一方，抜き取り検査で不合格とな り，全量廃棄となるロットにも健全なダイコンが含まれ，
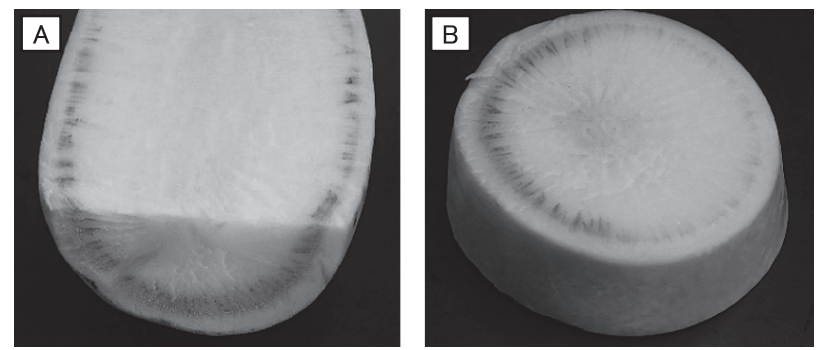

第1図 ダイコンのバーティシリウム黒点病症状

$\mathrm{A}$ : 首〜胴部の縦断面 表皮内側の維管束に黒変症状が見られる（指数 3 の 試料)

$\mathrm{B}$ : 首部の横断面

維管束にリング状の黒変症状が見られる（指数 2 の 試料) 
生産物の損失につながる.

その対策として, 内部障害が検出できる非破壊計測装置 を選果ラインに組み込み, 全量検査を行らのが有効と考兄 られる. 青果物の光学的手法による内部障害の非破壊計測 については, ジャガイモの内部障害 (澤山ら, 2001), メロ ンの水浸状果 (伊藤, 2007), パイナップルの熟度と内部罹 病果 (大森, 2003), ナツダイダイのス上がり果 (鈴木・石 田，1979），ナシのみつ症（猪俣, 1989）, リンゴの密入り 果 (Tsuchikawa ら, 2002) 扎よび褐変果肉果 (Clark ら, 2003) などの報告がある. ダイコンについては, 赤心症および黒 心症を透過光の RGB 分析により判別する方法（谷本ら， 2003), および黒斑細菌症を近赤外分光法により判別する方 法（中野，2007）が報告されている. しかしながら，いず れの報告に颃いても，本研究で対象とするバーティシリウ ム黒点病の判別については未検討である.

現在, 選果施設で受け入れられたダイコンは, 水洗後コ ンベア上で人手抢よび外観選別機により, 曲がり, 分岐根, 表皮の傷などの外観および規格により選別されている。し かし, 内部障害については外観による判別が困難なため, ライン上での全量選別は実施されていない，そこで本研究 では, 可視・近赤外分光法を用いて, ダイコンのバーティ シリウム黒点病症状を選果ライン上で連続的に計測・選別 する方法を検討した.

\section{材料および方法}

\section{1. 供試試料}

試料は 2008 年 8 月 7 日扝よび 12 日に北海道内産地で収 穫された“夏つかさ’で，選果場に拮いでーティシリウ ム黒点病症状が確認されたロットから採取し，140点を供 試した. 供試試料の重量は, 平均 $1,219 \pm 167 \mathrm{~g}$ (標準偏差), 最小 $906 \mathrm{~g}$ および最大 $1,598 \mathrm{~g}$ である. 測定前処理は通常の 選果行程と同様に, 茥葉を長さ $10 \mathrm{~cm}$ に切り揃え, 根部を 水洗した. その後, 個々の供試試料が判別できるように,
あらかじめ茎葉部に識別番号を記入したラベルを装着し た.スペクトル执よび発病程度の計測は収穫翌日に行った.

\section{2. 計測機器およびスペクトル測定方法}

試料搬送コンベア 1 系統・選別用コンベア 2 系統および 光源と受光部からなるセンサーボックスで構成する計測機 器を試作した (第 2 図).コンベアは, ダイコン試料が安定 するよらに中央に窪みを付けた V 字型バケットを $23 \mathrm{~cm}$ ピッチで連結した構造であり，計測に際して，ダイコンは 進行方向に対して横向き，すなわち，ダイコンの長軸方向 とコンベア進行方向が直交するように置かれる(第 2 図 B). ダイコンを人手により各バケット上に置き, 毎分 $11 \mathrm{~m}$ の搬 送速度でセンサーボックスへ供給した。計測方式は，反射 光では表皮直下のごく浅い部分の評価にとどまり内部症状 計測の精度が劣ることが想定されたため, 透過光を計測す ることとした. 光源は $50 \mathrm{~W}$ ハロゲンランプ 2 灯で, 外部 光を遮断したセンサーボックス内の上部に装着し，それぞ れダイコン上面の首側と尻側から照射するように設置し た. 受光部は，ダイコン下面の中央部から透過光を受光で きる位置のコンベア下部に設置した. 分光器は, 受光部か ら光ファイバーを経由した光をスリット通過させ, グレー ティングにより分光した後, CCD で受光して光強度を計測 する構造とした（第 2 図 C). スペクトル測定は, コンベア 上で連続的に試料を搬送しながら，可視掞よび近赤外領域 （測定波長範囲 $450 \sim 1,000 \mathrm{~nm}$ ）の透過光スペクトルを計 測した。

\section{3. 発病程度の指数化}

スペクトル測定後のダイコンを切断して発病程度を目視 により指数化した. すなわち，バーティシリウム黒点病症 状は首部を中心に発現し, しだいに尻部へ拡大するため, 首部を包丁で輪切りにし, 切断面の黒点病症状を観察によ り指数化した (第 3 図). 指数は, 無症状 $(0)$, 維管束の黒 点がわずかで切断面の半周未満に発現 (1), 維管束の黒点 が半周以上に発現 (2), 維管束の黒点が全周に明確に発現
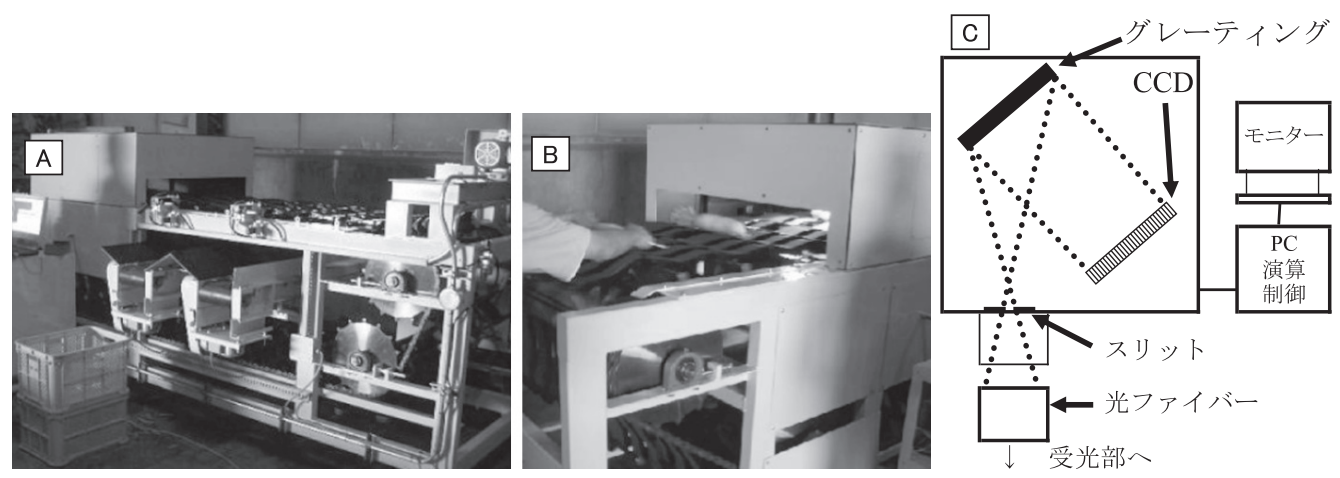

第 2 図 ダイコン搬送用コンベアを装備した内部品質計測・選別機

\section{A : 試料排出側からの機器外観}

左側の白いボックスがセンサー部分

上部の搬送用コンベアに直交して，下部に 2 系統の排出ラインを付属

B : 試料搬入側の機器外観

$\mathrm{C}$ : センサー構造の模式図 


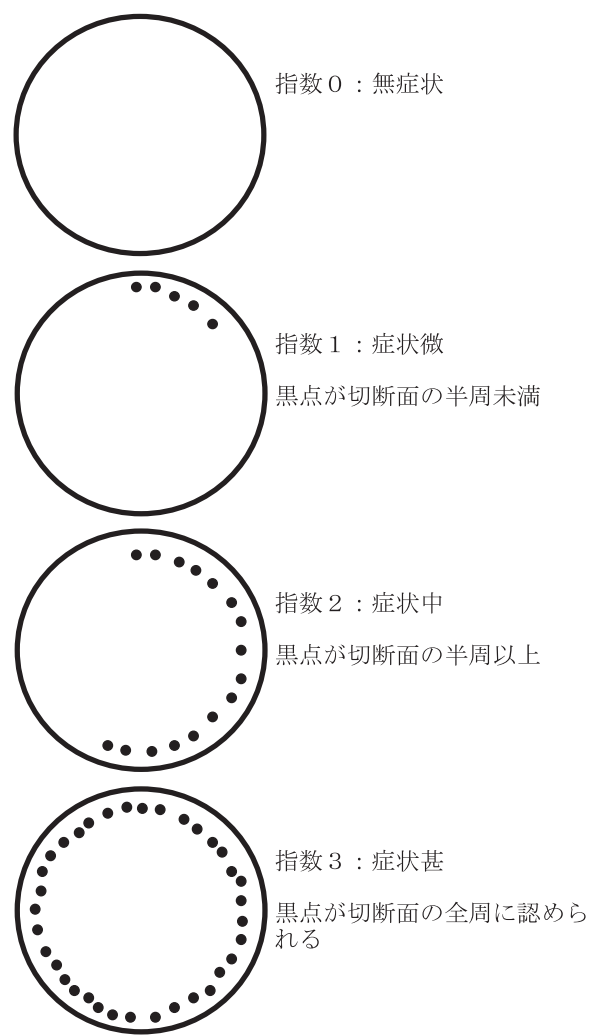

第 3 図 バーティシリウム黒点病の発病指数

首部を切断し, 断面の黒点症状を目視により指数化した

（3）の 4 段階とした.

\section{4. 検量線作成および評価}

試料を 70 個体ずつ 2 群に分け, 一群を用いて 2 次微分 スペクトルと発病指数から PLS 回帰分析により検量線を作 成した。 その後, 他群を検量線評価用として, その 2 次微 分スペクトルから発病指数の推定值を算出し, 相関係数 （R）拈よび予測標準誤差（SEP，推定值と目視による評点 の残差の標準偏差）から計測精度を評価した。

\section{結果および考察}

バーティシリウム黒点病症状は, 主に維管束の黒変に加 え，感染による水分执よびその他の内部成分含量の変化も 想定されたため，可視〜近赤外領域の波長を計測すること とした. バーティシリウム黒点病の発病指数が広く分布す る試料群を供試し(第 1 表)，スペクトル計測を行った。そ の結果, 透過光 2 次微分スペクトルの主な極小ピークは 560，740 および $840 \mathrm{~nm}$ 付近，極大ピークは 580, 720 打よ

第 1 表 供試試料に打ける発病指数の分布

\begin{tabular}{cccccc}
\hline \hline \multirow{2}{*}{$\begin{array}{c}\text { 供試試料 } \\
\text { の用途 }\end{array}$} & \multicolumn{5}{c}{ 発病指数 } \\
\cline { 2 - 5 } & 0 & 1 & 2 & 3 & 計 \\
\hline 検量線作成用 & 18 & 13 & 28 & 11 & 70 \\
検量線評価用 & 17 & 14 & 27 & 12 & 70 \\
\hline
\end{tabular}

表中の数字は供試個体数
び $820 \mathrm{~nm}$ 付近に認められた（第 4 図）。この時，発病指数 が 0 抢よび 3 の試料間のスペクトルを比較すると，両者に 明確な違いが認められた。すなわち，スペクトルの主要な ピークに拈ける吸光度の絶対值は，発病指数が 0 のものに 比べ 3 の試料で小さかった

検量線作成用試料を計測して得られた $450 〜 1,000 \mathrm{~nm}$ の 吸光度を 2 次微分処理し，その波長範囲の $1 \mathrm{~nm}$ ごとのす べての值と目視による発病指数をもとに，PLS 回帰分析に より検量線を作成した。 その結果，検量線作成用試料にお いて，相関係数 $\mathrm{R}=0.979 （ 0.1 \%$ 水準で有意差あり），検量 線標準誤差 $\mathrm{SEC}=0.211$ であった（第 5 図 A）。この検量線 を用いて, 評価用試料の 2 次微分スペクトルから発病指数 の推定值を算出した結果， $\mathrm{R}=0.958 （ 0.1 \%$ 水準で有意差あ り）, 予測標準誤差 SEP = 0.299 であった（第 5 図 B）.

本試作機では発病指数による選別, すなわち出荷用ライ ンと除外用ラインへの振り分け制御を任意の発病指数（推 定值）で設定できる。そのため，評価用試料群を対象に， “推定值 1”を閾值として症状の有無を判定すると，発病指 数 0 (無症状) の試料は $100 \%$ “症状なし”, 発病指数 1 以 上の試料は $91 \%$, 発病指数 2 以上の試料は $100 \%$ が “症状 あり”と判定できる（第 5 図 B)。 また，発病指数 0 の試料

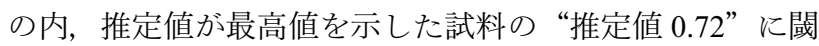
值を設定した場合，発病指数 1 以上の試料は $98 \%$ が “症状 あり”と判定できる。メロンに拈ける生理障害果の非破壊

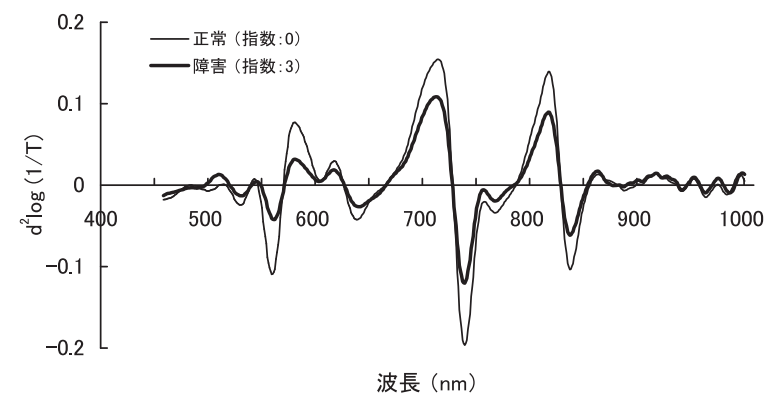

第 4 図 バーティシリウム黒点病の発病指数の異なるダイコ ンの透過光 2 次微分スペクトル

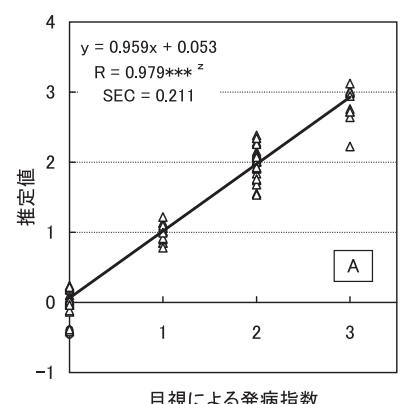

目視による発病指数

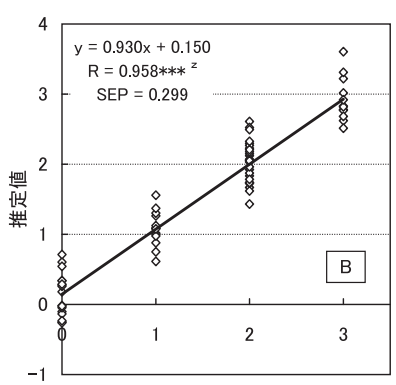

目視による発病指数
第 5 図検量線作成用試料および評価用試料の目視による発 病指数と発病指数推定值との関係

$\mathrm{z} * * *$ は $0.1 \%$ 水準で有意差あり

$\mathrm{A}$ : 検量線作成用試料, B : 検量線評価用試料 
計測では正答率が 83\%（伊藤，2007），ナツダイダイにお けるス上がり果では全階級対象で正答率が最高 91\%（鈴 木・石田，1979）であった。 これら他品目で検討された知 見と比較しても, 本報告での結果は同等以上の精度である と判断された.

現地の選果場では, 約 500 本のダイコンが入った大型コ ンテナからわずか 5 〜 15 本の抜き取り検査により受け入れ 可否を決定し, 基準以上の内部障害が認められたロットは すべて廃棄処分としている. しかしながら, 同一ロット内 での内部障害発生はダイコン一本一本で必ずしも均一では ない，このため，抜き取り検査で受け入れ基準を満たした ロットに, 内部障害のあるものが混入することも危惧され る. 一方, 抜き取り検査で廃棄処分となるロットにも健全 なものが含まれることが想定され，これは生産物の損失に つながる. 本研究で開発した全量検査のシステムを利用で きれば, バーティシリウム黒点病症状のあるダイコンは一 本一本，わずかな症状でも検出，除去が可能であり，とり わけ発病指数が 2 以上のものの混入はほとんど生じないと 考えられる(第 5 図 B).

発病指数の計測にあたって, 2 次微分スペクトルのどの 波長の吸光度が推定值と相関が高いかを検討した。 その結 果, 最も正の相関が高かった波長帯は $580 \sim 610 \mathrm{~nm}$ 付近 で, 最も負の相関が高かった波長帯は $550 〜 560 \mathrm{~nm}$ 付近 であり，いずれも可視光域であった（第 6 図）。本症状が肉 眼で観察可能な維管束の黒変であることから, 可視光域の 吸収と相関が高くなったと推定される，果実類の糖含量な ぞの非破壊計測では近赤外領域の吸収スペクトルが利用さ れる例が多いが（伊藤，2007; 伊豫・河野，2001; Kawano ら，1992, 1993; 大場ら，2001），ナッダイダイのス上がり 果判定では可視および近赤外領域の吸光度が利用されて拉 り（鈴木・石田, 1979), パイナップルの熟度および内部罹 病果の判定では透過光の輝度が利用されている（大森, 2003).これらの知見と合わせ, 前述のとおりバーティシリ ウム黒点病の発病指数は可視光領域の吸光度と相関が高 かったことから, 今後, 障害部位に着色を伴う内部障害の 非破壊評価では可視光域での吸収スペクトル計測も重要に なると推察される. 一方, 可視光域の吸収と発病指数の相 関が高かったことから, 根表面の付着土の影響も懸念され

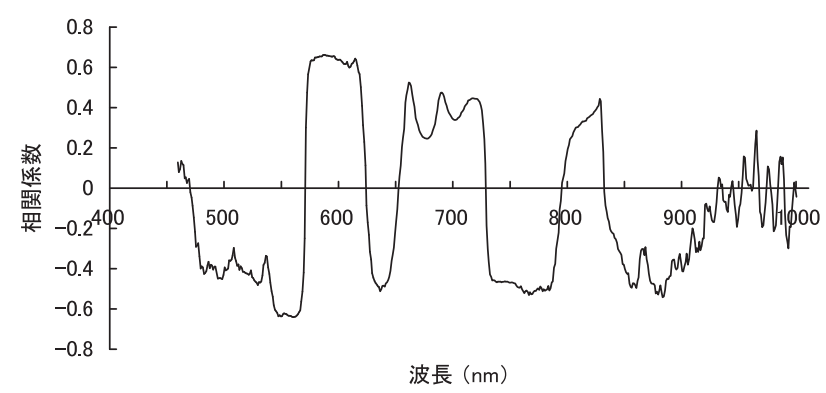

第 6 図 発病指数推定值と各波長毎の吸光度の相関関係
るが，通常のダイコン選果システムでは収穫物の受け入れ 直後に水洗され，その後にラインへ搬送されるため，発病 指数の推定精度に大きな影響は及ぼさないと考えられる.

以上のように, 可視・近赤外分光法により, ダイコンの バーティシリウム黒点病症状を選果ライン上で連続的に精 度良く非破壊計測拈よび選別できることが示唆された。 ま た，供試試料の搬送に用いたコンベアの運転速度は，既存 のダイコン選果場のものに匹敵する分速 $11 \mathrm{~m}$ であることか ら選果効率上の問題もないと判断された．今後，実用化に 当たって品種，作期および産地が異なる試料での評価精度 の確認も必要と考えられる。また，本症状以外に年次・収 穫時期毎に時折発生する外観判別困難な内部障害について も非破壊計測法が検討され，総合的な品質計測・選別シス テムとして確立されることが期待される.

\section{摘 要}

ダイコンのバーティシリウム黒点病は外観での判別が困 難であるため, 選果後も一部が正常な出荷物に混入し, 流 通上の問題となる場合がある。 そこで, 我々は選果ライン 上で，可視・近赤外分光法により本症状を非破壊計測する 方法を検討した. 可視・近赤外分光法による 2 次微分スヘ クトルは，発病指数に応じた明確な差が認められた． 2 次 微分スペクトルと発病指数 $(0 \sim 3$ の 4 段階 $)$ から PLS 回 帰分析により検量線を作成し，これを別の試料に適用して 精度を評価した。その結果，本法で推定した発病指数と実 際の発病指数との間の相関は $\mathrm{R}=0.958(0.1 \%$ 水準で有意差 あり), $\mathrm{SEP}=0.299$ となり, 高精度な推定が可能と判断さ れた. 推定発病指数の 1 を閾值として症状の有無を判定す ると, 実際の発病指数 0 (無症状) の試料は $100 \%$ “症状な し”と判定され，指数 1 の試料は $91 \%$, 指数 2 以上の試料 は $100 \%$ が “症状あり”と判定された. 推定発病指数と正 の相関が高かった 2 次微分スペクトルの波長帯は580〜 $610 \mathrm{~nm}$ 付近で, 最も負の相関が高かった波長帯は550 $560 \mathrm{~nm}$ 付近であった.

\section{引用文献}

Clark, C. J., V. A. McGlone and R. B. Jordan. 2003. Detection of brownheart in 'Braeburn' apple by transmission NIR spectroscopy. Postharvest Biol. Technol. 28: 87-96.

猪俣雄司. 1989 . ニホンナシ「豊水」のみつ症の非破壊測 定. 今月の農業. 33: 94-97.

伊藤秀和. 2007. 近赤外分光法によるメロン品質の非破壊 計測法の開発. 野菜茶研研報. 6: 83-115.

伊豫知枝・河野澄夫. 2001. 貯蔵がリンゴ果実の近赤外ス ペクトルに及ぼす影響. 園学雑. 70: 510-515.

Kawano, S., T. Fujiwara and M. Iwamoto. 1993. Nondestructive Determination of sugar content in satsuma mandarin using near infrared (NIR) transmittance. J. Japan. Soc. Hort. Sci. 62: $465-470$. 
Kawano, S., H. Watanabe and M. Iwamoto. 1992. Determination of sugar content in intact peaches by near infrared spectroscopy with fiber optics in interactance mode. J. Japan. Soc. Hort. Sci. 61: 445-451.

北沢健治・鈴井孝仁. 1980. ダイコンのバーティシリウム 黒点病. 日植病報. 46: 271-273.

小松 勉・角野晶大・北畠国昭・柳山浩之. 2001a. ダイコ ンバーティシリウム黒点病に対するダゾメット粉粒剤 の防除効果 (3) 根雪前無被覆処理の効果. 北日本病虫 研報. 52: 53-55.

小松 勉・角野晶大・北畠国昭・柳山浩之. 2001b. ダイコ ンバーティシリウム黒点病に対するダゾメット粉粒剤 の防除効果 (4) マルチ畦内処理と抵抗性品種の組久合 わせ効果. 北日本病虫研報. 52: 56-58.

中野和弘. 2007. 内部障害を有する大根の非破壊判定方法 及びその装置. 特許公開2007-71603.

大場聖司・荒川 博 - 松浦英之・中根 健 - 水野俊博. 2001 . 近赤外分光法による温室メロン糖度非破壊測定機の開 発. 静岡農試研報. 46: 11-22.

大森定夫. 2003. 食品の非破壊計測ハンドブック . p. 127130. サイエンスフォーラム。東京.

澤山一博・本間稔規・青山達仁. 2001. 光学的手法を用い
た根菜類品質検査技術の開発. 北海道立工業試験場報 告. 300: 155-158.

角野晶大 ・ 北畠国昭 - 佐々木高行 - 柳山浩之 - 小松 勉 田中民夫. 2001a. ダイコンバーティシリウム黒点病に 対するダゾメット粉粒剤の防除効果 (2) 三重ポリエチ レンフィルムを用いたマルチ畦内処理. 北日本病虫研 報. 52: 49-52.

角野晶大 - 北畠国昭 - 柳山浩之 - 田中民夫 - 佐々木高行. 2001b. ダイコンバーティシリウム黒点病に対するダท゙ メット粉粒剂の防除効果 (1) 処理量と処理深度. 北日 本病虫研報. 52: 45-48.

角野晶大・田中民夫・富沢雅代・鈴木清史. 1997. Verticllium albo-atrum によるダイコンバーティシリウム黒点病の 発生 (病原の追加). 日植病報. 63 (講演要旨) : 203 . 鈴木晴夫・石田 隆. 1979. 透過光の利用による夏橙の「ス 上がり果」の選別. 静岡柑試研報. 15:23-28.

谷本政男・藤井 茂・田村 学. 2003. 根菜類の欠陥の非 破壊検査装置. 特許 3389098 .

Tsuchikawa, S., S. Kumada and K. Inoue. 2002. Application of time-of -frighit near-infrared spectroscopy for detecting water core in apples. J. Amer. Soc. Hort. Sci. 127: 303-308. 